\title{
THE EFFECT OF INDEPENDENCE, EXPERIENCE, AND GENDER ON AUDITORS ABILITY TO DETECT FRAUD BY PROFESSIONAL SKEPTICISM AS A MODERATION VARIABLE
}

\author{
Megawati Shofia \\ Independent Researcher, Indonesia \\ E-mail: shofia.megawati@gmail.com
}

\begin{abstract}
This study aimed to empirically examine the effect of independence, experience, and gender on the auditor's ability to detect fraud by professional skepticism as a moderating variable. It used 84 respondents, they were BPK RI auditor Representative of East Java Province. The analytical method used Moderated Regression Analysis (MRA) with SPSS 20.00 for Windows. The results of the study indicated that independence and experience had a significant positive effect on the auditor's ability to detect fraud. While gender had a positive but not significant effect on the auditor's ability to detect fraud. In addition, the results of this study also showed that professional skepticism was able to moderate the relationship between independence, experience, and gender to the auditor's ability to detect fraud.
\end{abstract}

\section{KEY WORDS}

Independence, experience, gender, professional skepticism, auditor, detecting fraud.

Fraud which was occuring in the private sector and government is one of the crimes that harm to society. The act of cheating seems to be considered as a common thing in various countries, both developed and developing countries, including Indonesia. There have been frequent reports lately both on television and in the mass media regarding acts of fraud which have resulted in the detention of several government officials in Indonesia. This illustrates that fraud in Indonesia, especially in the government sector is very alarming and must be dealt with seriously. The government sector is required to maintain quality, professionalism, and accountability in carrying out its activities, so that fraud and misuse in the management of state finances do not occur (Subsiyani, 2017). This indicates that an audit is required by an independent third party to assess the fairness of the financial statements prepared by government institutions.

The Republic of Indonesia Supreme Audit Agency (BPK RI) as a government external auditor is an independent financial audit body that conducts checks on the management and accountability of state finances. The external auditor must ensure that the financial statements prepared are in accordance with applicable standards and reflect the actual conditions of the work unit. In addition, external auditors must also ensure that the report does not contain material misstatements, whether caused by fraud or fraud. In carrying out its audit tasks, the BPK has a benchmark in conducting checks on management and responsibility of state finances, namely the State Financial Inspection Standards (SPKN). Examination of management and responsibility of state finance is carried out to create a clean and free government from corruption, collusion and nepotism (BPK RI, 2017).

The results of the ACFE Indonesia Chapter survey conducted in 2016 showed that external auditors ranked second out of twelve as those who detected fraud with a percentage of $16.5 \%$. This is interesting, because the survey conducted in 2014 showed that external auditors were ranked seventh out of twelve with a percentage of only $3 \%$. There are several previous studies regarding the auditor's ability to detect fraud. Idawati \& Gunawan (2015) found that independence was influential in efforts to detect fraud. In addition to independence, professional skepticism and competence also affect the auditor's ability to detect fraud (Hartan, 2016).

However, Nadhira (2018) found that independence did not affect fraud detection capabilities. He stated that the more independent the auditor, the auditor will tend to 
complete his task independently without seeking more information about the evidence that supports the management assertion of his client. A high audit experience from an auditor also does not affect the increase in fraud detection capabilities (Diana, 2016).

In addition, Yendrawati \& Mukti (2017) also found that gender had no effect on efforts to detect fraud. He stated that men and women have the same ability to analyze information obtained during the inspection process. The skepticism that the auditor has when conducting an examination also does not affect the auditor's ability to detect fraud (Suryanto et al., 2016). Cory (2015) found that auditor professional skepticism was able to strengthen the auditor's experience relationship with fraud detection. Whereas Bangun (2017) actually found that professional skepticism did not affect the relationship between independence and gender towards the ability to detect fraud.

Attribution theory studies the process of how someone interprets an event, reason, or cause of behavior. Attribution Theory was developed by Heider (1958) which states that a person's behavior is determined by two factors, namely internal factors and external factors. The internal factor in question is a factor that comes from within a person such as the ability or effort made by someone. While what is meant by external factors are factors that come from outside a person. Kelley (1973) mentions that attribution theory can answer questions about social perception as well as self-perception. When an auditor faces a red flag when conducting an audit, the auditor will try to find the cause and make conclusions about the red flags. An auditor's self-perception will play an important role in concluding whether red flags lead to symptoms of cheating or not. Behavior and Behavior Theory was developed by Triandis (1971) which states that behavior is determined by attitude, guidance on what is done, and what is usually done will determine the formation of a behavior. According to Fishbein \& Azen (1975) in Mentari (2018) something can be said as an attitude when fulfilling the following things: (1) attitudes can be learned, (2) attitudes defining responses and behavior of people towards what is being experienced, (3) attitude is governed by the core of personality. Behavior and behavior theory explains how the attitudes and guidelines used by the auditor will determine their behavior.

Fraud is an unlawful act carried out by people both inside and outside the organization, with the intention of gaining personal or group benefits that can directly harm others (Priantara, 2013: 4). However, there are several elements of fraud formation. These elements are:

1. There are false or misleading statements which can be in the form of a report, data or information, or proof of transaction;

2. There is abuse or utilization of position, occupation, and position for personal or group interests and benefits;

3. Supported by material facts, meaning that they must be supported by objective evidence and in accordance with the law;

4. The aggrieved party relies and is deceived by a statement made wrong that is harmful. That is, there are parties who suffer losses, and there are also those who obtain illegal profits or benefits in the form of money or assets or other economic benefits.

The ability to detect fraud is something that must be owned by the auditor because it shows the extent of the quality of the audit performed (Kartikarini, 2016). According to Tuanakotta (2010) detecting fraud is an attempt to get sufficient initial indications of fraud, while at the same time narrowing down the space for fraud perpetrators. Mui (2010) in Pramana (2016) states that fraud detection is an unstructured task that requires the examiner to produce alternative methods as well as to seek additional information from various sources encountered during the examination. In an effort to detect fraud, most of the evidence of fraud obtained is indirect evidence.

The examiner must be responsible for continuously maintaining independence in independence of mind and independence in appearance (independence of mindfulness) (Arens et al., 2014: 102). In conducting audits, the examiner needs to consider three types of disruptions to independence, namely personal, external and / or organizational disturbances. If one or more of the interruption of independence affects the ability of the individual examiner to carry out his inspection duties, the examiner is required to reject the audit 
assignment (SPKN, 2017). The interests of users of financial statements may be different from one another. Therefore, independence is a mandatory thing that must be understood and owned by an auditor in carrying out his duties.

The auditor's experience is a measure of the length of time and duration of work that the auditor has passed in understanding his duties properly. Experience is a good way of learning for auditors because with high experience it will make auditors rich in audit techniques (Biksa \& Wiratmaja, 2016). In general, audit experience is indicated by the auditor's flight hours in carrying out inspection tasks. Auditors who have high experience will understand more about the causes of fraud (Armanda, 2014). With a lot of experience, the auditor will not only be able to detect fraud, but the auditor is also able to provide a more accurate explanation of the findings (Suryanto et al., 2017). Experienced auditors will have more knowledge about mistakes and fraud so that they will produce better performance in detecting fraud cases compared to minimal experienced auditors (Pramana, 2016).

Hardies et al. (2011) in Kartikarini (2016) relates gender with behavior carried out by someone. In some studies, gender is related to male and female gender, but in other literature, gender is related to both masculine and feminine characteristics. Femininity and masculinity refer to things that determine the behavior of someone. Women tend to have feminine characteristics, while men tend to be masculine (Burke, 2000 in Kartikarini, 2016). Compared to men, women often behave more easily in believing in something. In doing a job, women tend to do things more thoroughly than men. Men tend to minimize cognitive effort in receiving information from clients. These things will make the attitude of professional skepticism vary in evaluating the quality and quantity of evidence used to support the audit report (Wake, 2017).

One of the most important attitudes that must be had when the examiner does his job is professional skepticism. The examiner must plan, carry out, and report on the examination with a professional attitude of skepticism. Hurt (2010) in Pramana (2016) states that professional skepticism itself does not have a definite definition, but from the definition of the word skepticism and professionalism it can be concluded that auditor professional skepticism is an attitude that always doubts and questions everything and critically assesses audit evidence. Skepticism does not mean unbelief, but seeks proof before believing a statement.

This study aimed to empirically examine the effect of independence, experience, and gender on the auditor's ability to detect fraud by professional skepticism as a moderating variable.

\section{HYPOTHESIS DEVELOPMENT}

Attribution Theory was developed by Heider (1958) which states that a person's behavior is determined by two factors, namely internal factors and external factors. The internal factor in question is a factor that comes from within a person such as the ability or effort made by someone. In addition, the Attitude and Behavior Theory developed by Triandis (1971) shows that the need for attitudes and guidelines used by auditors in order to determine their behavior in detecting fraud, one of which is having an independent attitude and experience in the audit field.

Based on the results of empirical tests conducted by several previous researchers, the formulation of the hypothesis of this study was:

- H1: Auditor independence had a positive effect on the ability to detect fraud;

- H2: Auditor experience had a positive effect on Ability to Detect Fraud;

- H3: Gender influenced the ability to detect fraud;

- H4: Professional skepticism moderated the relationship between Auditor Independence and Ability to Detect Fraud;

- H5: Professional skepticism moderated the relationship between Auditor Experience and Ability to Detect Fraud;

- H6: Professional skepticism moderated the relationship between Gender and Ability to Detect Fraud. 


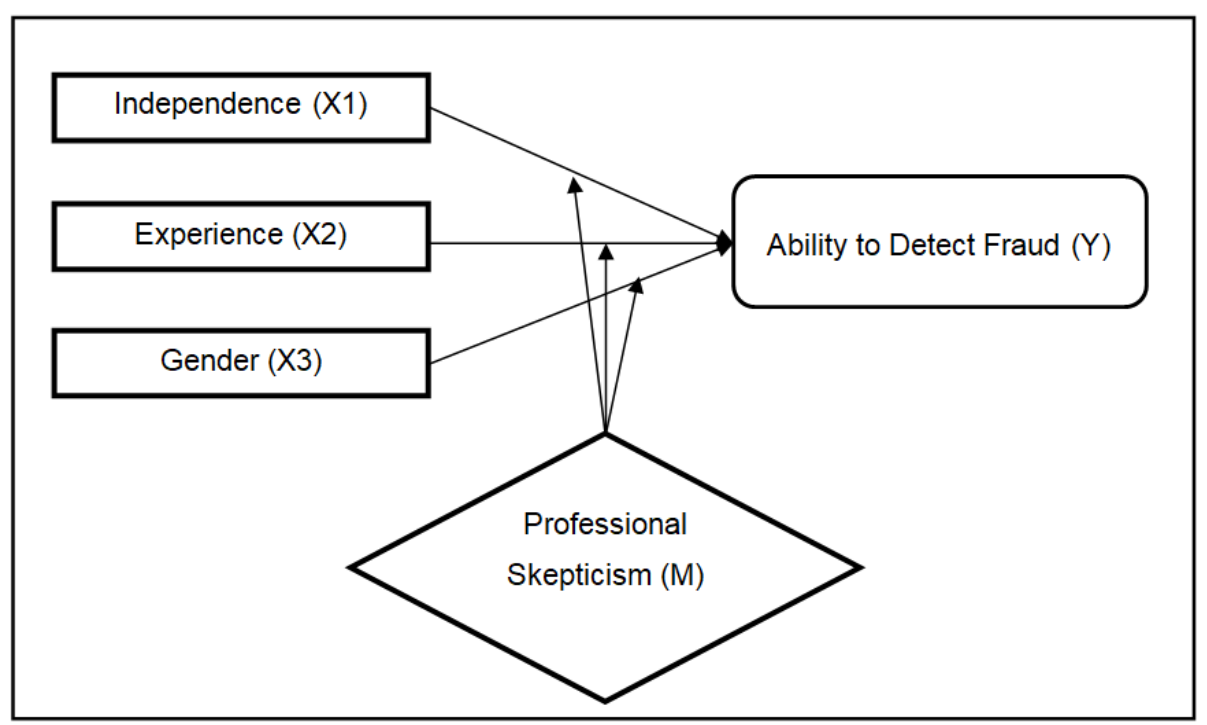

Figure 1 - Conceptual Framework

\section{METHODS OF RESEARCH}

The population of this study was all auditors working at the Republic of Indonesia BPK Representative Office in East Java. This study uses a portion of the population to be used as the research sample. The sampling technique using convenience sampling is used because the researcher cannot obtain complete auditor identity information. The data collection method used in this study is the survey method, which is the method of collecting primary data by retrieving data from the existing population. The analytical method used is the Moderated Regression Analysis (MRA) using SPSS 20.00 for Windows.

\section{RESULTS AND DISCUSSION}

In this section we will present the results of the test of the effect of Independence, Experience, and Gender on the Ability of Auditors to Detect Fraud with Professional Skepticism as a moderating variable using the statistical method Moderated Regression Analysis (MRA). The moderation regression analysis equation model was divided into 2 , as follows:

$$
\begin{gathered}
Y=a+\beta 1 X 1+\beta 2 X 2+\beta 3 X 3+e \\
Y=a+\beta 4 X 1+\beta 5 X 2+\beta 6 X 3+\beta 7 M+\beta 8 X 1{ }^{*} M+\beta 9 X 2 * M+\beta 10 X 2 * M+e
\end{gathered}
$$

Before testing the moderation regression analysis, the classic assumption test must first be carried out as a condition for the feasibility of the data for subsequent regression analysis.

The results of the normality test calculating from the first equation obtained using SPSS are as follows:

Table 1 - One-Sample Kolmogorov-Smirnov Test

\begin{tabular}{|c|c|}
\hline $\mathrm{n} / \mathrm{n}$ & Unstandardized Residual \\
\hline $\mathrm{N}$ & 84 \\
\hline Test Statistic & 0.061 \\
\hline Sig. & 0.200 \\
\hline
\end{tabular}

Based on table 1 above, the significance value of the test was 0.200 , which meant that the alpha value was greater (0.05). Based on these tests indicate that the residual distribution is normally distributed. 
To find out whether or not multicollinearity can be seen using the value of Variance Inflation Factor (VIF). If the VIF value was greater than 10, it indicates multicollinearity.

Table 2 - Multicollinearity Test

\begin{tabular}{|c|c|c|}
\hline Variable & Tolerance & VIF \\
\hline X1 (Independence) & 0.965 & 1.036 \\
\hline X2 (Experience) & 0.952 & 1.051 \\
\hline X3 (Gender) & 0.977 & 1.024 \\
\hline
\end{tabular}

Based on table 2 above, it could be seen that the VIF values of the three independent variables are smaller than 10 , so it can be concluded that there is no multicollinearity between independent variables.

The results for the normality test of equation 2 were as follows:

Table 3 - One-Sample Kolmogorov-Smirnov test

\begin{tabular}{|c|c|}
\hline $\mathrm{n} / \mathrm{n}$ & Unstandardized Residual \\
\hline $\mathrm{N}$ & 84 \\
\hline Test Statistic & 0.061 \\
\hline Sig. & 0.200 \\
\hline
\end{tabular}

Table 3 above shows the significance value of the Kolmogorov-Smirnov one sample test worth 0.200 , which means that the alpha value is greater than (0.05). Based on these tests indicate that the residual distribution is normally distributed.

The results for the multicollinearity test for equation 2 were as follows:

Table 4 - Multicollinearity Test

\begin{tabular}{|c|c|c|}
\hline Variable & Tolerance & VIF \\
\hline X1 (Independence) & 0.004 & 228.447 \\
\hline X2 (Experience) & 0.005 & 196.792 \\
\hline X3 (Gender) & 0.003 & 312.073 \\
\hline M (Professional Skepticism) & 0.005 & 214.111 \\
\hline X1.M & 0.002 & 662.253 \\
\hline X2.M & 0.002 & 573.667 \\
\hline X3.M & 0.003 & 323.051 \\
\hline
\end{tabular}

Table 4 shows that each independent variable has a VIF value of no more than 10 . This indicates that the assumption of multicollinearity tests has been fulfilled.

Regression analysis is used to obtain variables that affect the ability of the auditor to detect fraud, and to know the most dominant variables that affect the ability of the auditor to detect fraud. Based on the results of data processing obtained results as listed in table 5.

Table 5 - Regression Analysis Test Equation 1

\begin{tabular}{|c|c|c|c|}
\hline Variable & $B$ & $\mathrm{~T}_{\text {count }}$ & Sig. \\
\hline Constanta & 17.572 & - & \\
\hline X1 (Independence) & 0.286 & 2.794 & 0.007 \\
\hline X2 (Experience) & 0.411 & 4.125 & 0.000 \\
\hline X3 (Gender) & 0.268 & 1.463 & 1.047 \\
\hline
\end{tabular}

Explanation of regression models obtained based on table 5 above is as follows:

$$
Y=17,572+0.286 X 1+0.411 X 2+0.268 X 3+e
$$

The first hypothesis stated that independence has a positive effect on the auditor's ability to detect fraud. The regression results in table 1.5 show that the regression coefficient of the independence variable (X1) is 0.286 . This shows that independence has a positive effect on the auditor's ability to detect fraud. In addition, the table above also shows the value 
of the t count of the independence variable $(X 1)$ greater than t table $(2.794>1.990)$ or from a significance value smaller than alpha value $(0.007<0.050)$ which means statistically significant. Then it can be concluded that $\mathrm{H} 1$ is accepted because independence has a positive effect on the auditor's ability to detect fraud.

The second hypothesis stated that experience had a positive effect on the auditor's ability to detect fraud. The regression results in table 1.5 show that the experience variable regression coefficient $(X 2)$ is 0.411 . The coefficient shows a number that is positive which means that experience has a positive influence on the auditor's ability to detect fraud. Experience variables have a tcount greater than t table $(4.125>1.990)$ and a significance value smaller than alpha value $(0.05)$, which is equal to 0.000 . This statistically shows that experience variables have a significant influence on the auditor's ability to detect fraud. Based on this, it can be stated that $\mathrm{H} 2$ is accepted.

The third hypothesis stated that gender influences the auditor's ability to detect fraud. The regression results in table 1.5 show that the regression coefficient of the gender variable (X3) is 0.268 . This showed that independence has a positive effect on the auditor's ability to detect fraud. In addition, the table above also showed that the gender variable has a tcount smaller than t table $(1.463<1.990)$ and a significance value greater than the alpha value (0.05), which was equal to 1.047. This shows that gender has a positive but not significant influence on the auditor's ability to detect fraud. So it can be concluded that $\mathrm{H} 3$ is accepted.

Moderation regression analysis explains the effect of independent variables and interactions between independent variables and moderating variables on the dependent variable. The results of the regression analysis of data processing are shown in table 6 .

Table 6 - Regression Analysis Test Equation 2

\begin{tabular}{|c|c|c|c|}
\hline Variable & $B$ & $\mathrm{~T}_{\text {count }}$ & Sig. \\
\hline Constanta & 26.806 & - & \\
\hline $\mathrm{X} 1$ (Independence) & 2.043 & 2.384 & 0.017 \\
\hline $\mathrm{X}$ (Experience) & 1.569 & 4.184 & 0.042 \\
\hline $\mathrm{X}$ (Gender) & 7.739 & 1.426 & 0.158 \\
\hline $\mathrm{M}$ (Professional Skepticism) & 2.206 & 3.145 & 0.028 \\
\hline $\mathrm{X} 1 . \mathrm{M}$ & - & 2.271 & 0.028 \\
\hline $\mathrm{X} 2 . \mathrm{M}$ & 4.076 & 1.441 & 0.014 \\
\hline $\mathrm{X} 3 . \mathrm{M}$ & 1.276 & 1.353 & 0.180 \\
\hline
\end{tabular}

Based on table 6 above, the regression models obtained are:

$$
Y=26,806+2,043 X 1+1,569 X 2+7,739 X 3+2,206 M+2,073 X 1 * M+4,076 X 2 \text { * } M+1,276 X 3{ }^{*} M+e
$$

Based on the results of the regression analysis obtained above, it could be seen that all independent variables, namely independence, experience, and gender have a positive effect on the auditor's ability to detect fraud as the dependent variable. While for significance, the independence and experience variables have a significant effect on the auditor's ability to detect fraud. However, gender variables have a non-significant effect on the auditor's ability to detect fraud.

The fourth hypothesis in this study was that professional skepticism moderates the relationship between auditor independence and the auditor's ability to detect fraud. Table 1.6 shows that the interaction between the variables of independence (X1) and professional skepticism (M) on the variable ability of auditors to detect fraud $(\mathrm{Y})$ has a regression coefficient of 2.073 which means having a positive relationship. Then, the resulting tcount was also greater than the value of t table $(2,271<1,992)$ and the significance value is smaller than the alpha value $(0.028<0.05)$. Based on the results of the data processing, it could be seen that $\mathrm{H} 4$ is accepted.

The fifth hypothesis stated that professional skepticism moderates the relationship between auditor experiences with the auditor's ability to detect fraud. The results of data processing show that the interaction between experience variables (X2) and professional skepticism $(\mathrm{M})$ on the auditor's ability to detect fraud $(\mathrm{Y})$ had a regression coefficient of 4,076 
which means having a positive relationship. The significance value produced is equal to 0.014 which meant it was smaller than the alpha value $(0.05)$. This shows that if there is an increase in interaction between experience variables (X2) and professional skepticism, it will increase the auditor's ability to detect fraud $(\mathrm{Y})$. So, it can be concluded that H5 was accepted.

The sixth hypothesis as well as the final hypothesis in this study was that professional skepticism moderates the relationship between gender and the auditor's ability to detect fraud. Table 1.6 shows that the interaction between gender variables (X3) and professional skepticism (M) on the auditor's ability to detect fraud $(\mathrm{Y})$ has a regression coefficient of 1,276 which meant has a positive relationship. In addition, table 1.6 also showed a significance value of 0.180 which means it was not significant because it was greater than the alpha value (0.05). The regression coefficient that produces a positive value explains that if there is an increase in the interaction of gender variables (X3) with professional skepticism (M) it will increase the auditor's ability to detect fraud $(\mathrm{Y})$, but not significantly because the significance value is greater than alpha. So, it can be stated that $\mathrm{H} 6$ is accepted.

\section{DISCUSSION OF RESULTS}

The results of testing the first hypothesis indicated that auditor independence has a positive effect on the auditor's ability to detect fraud. This showed that the more independent an auditor was, the auditor's ability to detect fraud will also increase. However, the results of this study are not in line with the results of Nadhira's research (2018) which showed that auditor independence has a negative effect on the auditor's ability to detect fraud. The results of this study were supported by the research of Pramudyastuti (2014) and Pramana (2016) which shows that independence has a positive and significant effect on the auditor's ability to detect fraud. So, it can be concluded that an auditor who always adheres to an independent attitude, the auditor will be better able to detect fraud, because the auditor will not side with any party if he finds a fraud during the inspection process.

The results of this study which showed that the auditor's experience has a positive effect on the auditor's ability to detect fraud indicate that the more auditor experience in conducting audits, the auditor's ability to detect fraud will also increase. The results of this study were supported by the results of research by Armanda \& Ubaidillah (2014) and Suryanto et al. (2017) which also shows that the auditor's experience has a significant positive effect on fraud detection capabilities. Research conducted by Kuria \& Muturi (2015) on external auditors in Kenya also shows that experience has a positive effect on the auditor's ability to detect fraud. Auditors with extensive experience in implementing audit procedures are not only able to determine the fairness of a financial statement, but the auditor will also be better able to find indications of fraud. So, it can be concluded that the more hours the auditor flies in auditing, the auditor's ability to detect fraud will also increase because the auditor's ability is increasingly honed.

The results of testing the third hypothesis indicated that gender has a positive effect on the auditor's ability to detect fraud, but did not significantly influence. According to Kushasyandita (2012) in Cory (2015) states that female auditors will be more thorough in investigating audit evidence and not easily trusting clients. In addition, he also stated that women tend to see clients from the emotional side, including body language and client nonverbal cues. The results of this study are supported by the results of a study by Kartikarini (2016) which shows that gender has a positive effect on the ability to detect fraud. He stated that the feminine attitude that is usually owned by women would make a person more flexible in placing behavior in different social situations, so that they would be better at understanding the signs of cheating.

The results of testing the fourth hypothesis indicated that the regression coefficient is positive. This explains if there is an increased interaction between independence and professional skepticism, it will increase the auditor's ability to detect fraud. The results of this study were in line with the results of research conducted by Biksa \& Wiratmaja (2016), Pramana (2016) who also tested the effect of professional skepticism on the ability to detect 
fraud. Fullerton \& Durtschi (2004) in Yatuhudika (2016) states that auditors with high skepticism will improve their ability to detect fraud by developing searches for additional information when faced with symptoms of fraud. So, it can be concluded that if an auditor did not believe in management assertions and does not favor anyone, then an auditor will be better able to detect fraud.

The results of testing the fifth hypothesis showed that skepticism strengthens the relationship between experience with the auditor's ability to detect fraud. The results of this study are supported by the results of the Parastika \& Wirawati (2017) study which also shows that professional skepticism is proven to strengthen the influence of auditor experience on the ability to detect fraud. In addition, he also stated that experience can affect the auditor's predictive ability and detection of fraud. Winantyadi and Waluyo (2014) state that the more auditors conduct audit of financial statements, the higher the level of skepticism. So, it can be concluded that if an auditor has a high level of skepticism, it will strengthen the influence of the auditor's experience on the ability to detect fraud.

The results of this study indicated that the interaction between gender variables and professional skepticism towards the auditor's ability to detect fraud had a positive, but not significant, relationship. This was in line with the results of Cory's research (2015) which states that gender has a positive effect on the ability to detect auditors. Yuniarti's (2018) study which also uses professional skepticism as a moderating variable also showed that skepticism was able to strengthen the relationship between gender and the auditor's ability to detect fraud. He also stated that many auditor capabilities are determined by internal attribution. One decisive internal attribution was the gender and professional skepticism that the auditor has. With the attitude of professional skepticism in the auditor will facilitate the auditor in analyzing the presence or absence of fraud in the financial statements so that the auditor will increase the detection of fraud in the subsequent inspection process (Hartan, 2016).

\section{CONCLUSION AND SUGGESTIONS}

This study examined the effect of independence, experience, and gender on the ability of auditors to detect fraud by professional skepticism as a moderating variable. Based on the results of the study it could be concluded that auditor independence and experience had a significant positive effect on the auditor's ability to detect fraud, while gender had a positive but not significant effect on the auditor's ability to detect fraud. In addition, based on the results of the study it can also be concluded that professional skepticism was able to moderate the relationship between independence, experience, and gender to the auditor's ability to detect fraud. In the process of conducting research, researchers faced several limitations when was conducting research. The first limitation was that the results of this study cannot be generalized because this study used convenience sampling techniques. This study was not able to use random sampling techniques because researchers have difficulty getting a complete list of auditors. Then, the return rate of the questionnaire was not $100 \%$ because when the researcher conducted the research, some auditors had not returned from the inspection assignment in the regional government. For further researchers, it was recommended to distribute questionnaires when the auditor had returned from the inspection assignment in the regional government so that the return of the questionnaire can be maximized. In addition, further researchers can also enhanced external factors that might have an influence on the auditor's ability to detect fraud.

\section{REFERENCES}

1. Arens, A. A., Randal, J. E., Mark, S. B. (2014). Auditing and Assurance Services. Jakarta: Erlangga.

2. Armanda, R., and Ubaidillah. (2014). The Effect of Professional Ethics, Knowledge, Experience, and Independence on the Audit Judgment at the South Sumatra Representative Audit Board. Journal of Management and Business Vol. 12 No. 2. 
3. Association of Certified Fraud Examiners (ACFE) Indonesian Chapter. (2016). Indonesian Fraud Survey 2016. Accessed from www.acfe-indonesia.or.id

4. Atmaja, D. (2016). The Influence of Competence, Professionalism and Audit Experience on the Capability of the Republic of Indonesia BPK Auditors in Detecting fraud with Computer Assisted Audit Techniques as Moderating Variables. Media Research Accounting, Auditing \& Information Vol. 16.

5. Bangun, R. (2017). Effects of Gender, Type of Personality, Independence, and Auditor Competence on Providing Auditor Opinions with Professional Skepticism as Moderating Variables. Thesis. FEB University of North Sumatra.

6. Biksa, I.A.I, and Wiratmaja, I.D.N. (2016). Effects of Experience, Independence, Auditor Professional Skeptism on Fraud Detection. Accounting E-Journal of Udayana University Vol. 17 p. 2384-2415.

7. Republic of Indonesia BPK. (2017). Regulation of the Republic of Indonesia Supreme Audit Board concerning the State Audit Standards. Accessed from www.bpk.go.id

8. Cory, E. (2015). Effect of Auditor Experience, Interpersonal Ability, and Gender on Fraud Detection with Professional Skepticism as a Moderating Variable. Thesis. FEB Bandung Islamic University.

9. Diana. (2016). Effect of Auditor Experience, Independence, Time Pressure, and Workload on the Auditor's Ability to Detect Fraud. Thesis. FEB Lambung Mangkurat University.

10. Ghozali, I. (2009). Application of Multivariate Analysis with the SPSS Program. Semarang: Diponegoro University Publishing Agency.

11. Hartan, T. H. (2016). The Effect of Professional Skeptism, Independence and Competence on the Ability of Auditors to Detect Fraud (Empirical Study at the Inspectorate of the Special Region of Yogyakarta). Profita Journal Issue 3.

12. Idawati, W. and Gunawan, A. (2015). Effect of Competence, Independence, And Professional Skepticism Against Ability To Detect Fraud Action In Audit Assignment. ljaber Vol. 13 No. 7 Page. 5125-5140.

13. Kartikarini, N. 2016. Effects of Gender, Expertise, and Professional Skepticism on the Ability of Auditors to Detect Fraud. Thesis. FEB Gajahmada University Yogyakarta.

14. Kuria, P. and Muturi, W. (2015). The Relationship Between The Auditors Experience and Fraud Detection: A Case of Private Firms Within Thika Sub County, Kenya. European Journal of Business and Social Science Vol. 4 No. 4.

15. Mentari, T. (2018). Effect of Independence and Professionalism on the Performance of Government Internal Supervisory Apparatus (APIP) with Organizational Culture as a Moderating Variable. Thesis. FEB Universitas Brawijaya.

16. Mulyadi. (2002). Auditing. Jakarta: Salemba Empat.

17. Nadhira, A. (2018). Effect of Independence, Auditor Experience, and Professional Skepticism on the Auditor's Ability to Detect Fraud. Thesis. FE Maranatha Christian University Bandung.

18. Novita, U. (2015). Effect of Experience, Workload, and Training on Skepticism and the Auditor's Ability to Detect Fraud. Fekon Journal Vol 2 No. 1.

19. Parastika, N. P. E., and Wirawati, N. G. P. (2017). Professional skepticism as a variable moderating the effect of compliance pressure and auditor experience on fraud detection. Accounting E-Journal of Udayana University Vol 18.3.

20. Pramana, A.C. (2016). Effects of Professional Skepticism, Independence, and Experience on the Ability to Detect Fraud. Thesis. FEB Universitas Brawijaya Malang.

21. Pramudyastuti, O. L. (2014). Effects of Professional Skepticism, Training on Fraud Audit, and Independence on the Auditor's Ability to Detect Fraud. Thesis. FEB Gajahmada University Yogyakarta.

22. Priantara, D. (2013). Fraud Auditing And Investigation. Jakarta: Mitra Wacana Media.

23. Ramadhaniyati, Y., and Hayati, N. (2014). Effect of Professionalism, Motivation, Integrity, and Independence of the Internal Oversight Unit in Preventing Fraud. Jaffa Vol. 2 pp. 101-114. 
24. Sekaran, U., and Bougie, R. (2017). Research Methods for Business. Jakarta: Salemba Empat.

25. Subsiyani, A. (2017). Public Sector Performance Audit and Functional Supervision of Public Accountability at the Regional Work Unit in the Government of the City of Bondowoso. Thesis. FE Muhammadiyah University of Jember.

26. Suryanto, R., Indriyani, Y., Sofyani, H. (2016). Determinant of the Auditor's Ability to Detect Fraud. Journal of Accounting and Investment Vol. 18 No. 1 thing 102-118.

27. Tuanakotta, T. M. (2010). Forensic Accounting and Investigative Audit. Jakarta: Salemba Empat.

28. Winantyadi, N., and Waluyo, I. (2014). Effects of Experience, Expertise, Audit Situations, and Ethics on Auditor Professional Skepticism. Journal of Accounting and Investment Vol. 13 No. 1 thing 112-121.

29. Yatuhudika, N. R. (2016). Effects of Education, Audit Experience, Independence, and Workload on the Capability of Auditors to Detect Fraud. Thesis. FEB University of North Sumatra.

30. Yendrawati, R., and Mukti, D.K. (2015). Influence of Gender, Auditor Experience, Task Complexity, Obedience Pressure, Work Ability and Auditor Knowledge of Audit Judgment. Journal of Innovation \& Entrepreneurship Vol. 4 No. 1 thing 1-8.

31. Yuniarti, Y. (2018). Effects of Experience, Workload and Gender on Fraud Detection through Auditor Professional Skepticism. Proceedings of the 2018 National Seminar on Economic Education. 